\title{
Core of HR Strategy: System Thinking and HRM
}

\author{
Gürhan Uysal \\ Ondokuz Mayıs University, Samsun,Turkey
}

\begin{abstract}
Research topic of study is to discuss system approach in strategic HRM (Human Resource Management). It assumes system approaches as core of HR strategy. This study presumes that task performance is key to human resource management. Technical field knowledge increases task performance. Society for Human Resources Management, USA, applies technical HR knowledge for HR professionals in their certification programs. Research question is how various issues of HRM have an impact on effectiveness of HRM. Research methodology contains in-depth literature review to discuss research topic and agenda. Further, study explores various issues related with HRM field. They are personnel management, task performance, economical impact of HRM, and intellectual capital. Firms may compete in isomorphism context by intellectual capital policy. Personnel management is application of implementing organizational jobs by personnel as a traditional method. Task performance is key to employee's individual and department performance, and impact of HRM on economy may be observed on talent management and intellectual capital. There are three case studies in paper. Therefore, case study methodology is used in the study. To conclude, this study mentions importance of system approach in strategic HRM field. In addition, PM (Personnel Management) is interested with organizational jobs, and HRM focuses on employees, and performance, which is aligned with resource-based view theory.
\end{abstract}

Keywords: strategic HRM, HR system, HPWSs, performance

This study explores various issues in HRM (Human Resource Management). HRM-related issues are task performance, economic impact, intellectual capital, personnel management, and isomorphism.

Strategic Human Resource Management (SHRM) is based on system thinking. It explores impact of HR system on firm performance. Because HRM practices are interrelated in strategic HRM, which is defined as HR bundles by MacDuffie (1995). SHRM has two definitions so far: First definition is made by Devanna, Fombrun, and Tichy (1981), which is link between HRM and strategic management. HRM contributes to firms' goals for sustainable competitive advantage. Second definition is made by Wright and McMahan (1992). It describes link between HRM and organizational performance. There is wide discussion in literature about mediators between HRM and firm performance. For example, Huselid and Becker (1997) discussed HRM-firm performance relationship with High Performance Work Systems (HPWSs), i.e., HR system has an effect on firm performance.

This study considers HR system in SHRM. Accordingly, a firm applies SHRM in its organization through HR system. Huselid and Becker (1997) figured HR system by High Performance Work System (HPWS). An HPWS model might be established as follows (see Figure 1):

Corresponding author: Gürhan Uysal, Ph.D., associate professor, School of Business, Ondokuz Mayıs University, Samsun, Turkey; research fields: human resource management, organizational behaviour, performance. 


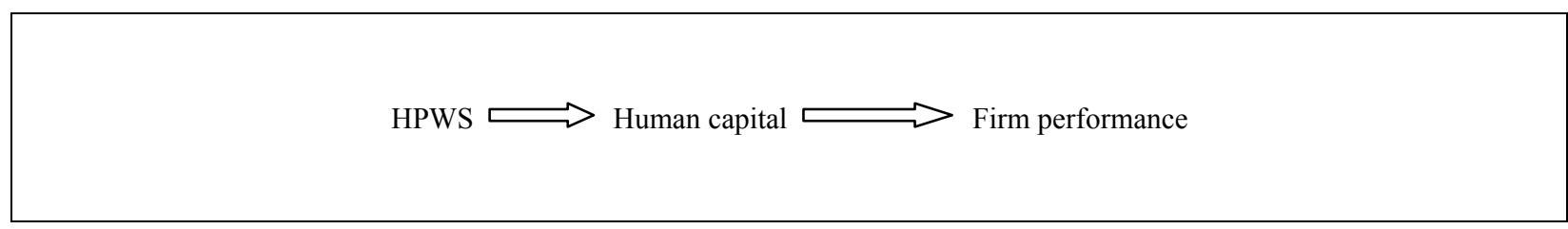

Figure 1. HPWS model.

Accordingly, it is assumption that HPWS is applied in organizations in order to develop human capital, and it is expected that human capital enhances individual performance. Huselid and Becker (1997) proclaimed that HPWSs reinforce employees' skills and behaviours. Further, HPWS is system that contains recruitment and selection, performance management, incentive compensation, and employee training and development.

\section{Personnel Management}

There are three human resource methodologies: personnel management, human resource management, and strategic human resource management. Each has historical chronology. But none of them is forgetten by businesses because each of them must be applied together.

Personnel Management (PM) is associated with "job performance". PM is oriented to increase job performance in firms. HRM is oriented to "employee performance". HRM aims to increase performance of employees through HRM practices. SHRM focuses on "firm performance". Both focus of PM and HRM is to increase firm performance. Therefore, firms apply three HR methods together in firms.

Firms do not ignore PM. Because it is related with organizational jobs, i.e., business functions. Firms have several business functions: production, marketing, logistics, supply, stock, accounting, finance, and others. Each has department and managers. PM considers that employees or personnel have to implement those functions, jobs.

Devanna et al. (1981) discussed the causes of turn from personnel management to human resource management. Main cause might be "economic shifts". In 1970s, international competition increased from Asia, especially from Japan. Therefore, firm perceived personnel as resources to become more competitive, which appears on Barney's (1991) resource-based view. According to Barney, firm obtains sustainable competitive advantage through its resources. Further, in American literature of firm management, determination of and involvement with strategy is key for organizational success. Therefore, human resource management gained strategy perspective during 1980s, i.e. human resources involvement with strategy development and executions.

\section{Impact of HRM on Competition: Intellectual Capital Dimension}

Impact of HRM on competition may be seen on intellectual capital dimension. Isomorphism is similarity among products in market, and intellectual capital may differentiate firm from rivals. Isomorphism is related to customer choice and competition. Isomorphism is explored with case study - auto market in this study.

How do customers have customer choice in isomorphism and full competition? And study aims to answer how a firm reacts for customer choice with ismorphism and full competition, because customers may have difficulty in customer choice among products in isomorphism.

Firms struggle for isomorphism and full competition in demand and in customer choice. Those two factors may lead to severe competition among firms in markets. For example, Toyota and Volkswagen recall their products. Firms may experience sales dilemma. 
Isomorphism is that firms produce similar products. For example, all higher education style and academic conferences are similar in globle. How does a student choose a university for higher education? For example, Harvard University develops case study technics early 1900s that differentiate it from competitiors. Therefore, firms may pursue differentiation strategy for full competitiveness and isomorphism. Differentiation is policy of Michael Porter, Harvard University, among competitive strategies.

Further, there are plenty of products in markets that result in full competitive structure. This study adopts case study methodology for research. It explores Samsun auto market in Turkey. Assumption is that Samsun auto market possesses full competitive and isomorphism structure.

Samsun auto market has full competitive structure, and it explores how a firm competes in a full competitive environment. Because global economy may have two structures: full competitiveness and isomorphism effects. Products are similar to each other (isomorphism), and firms possess sales pressure under isomorphism effect. What kind of business policy may a firm pursue in the market of isomorphism and full competitiveness? Answer might become differentiation strategy. Supposing there are 500 unit cars in auto market, and there is only 1-2 sales daily. How do others compete? Products are similar and customers have customer choice dilemma. Firms may pursue differentiation strategy. Intellectual capital may differentiate firm from competitiors. For example, a car company may decrease $\mathrm{CO}_{2}$ emission, or seat in cars has heating system inside, and seats release warm climate into automobile.

Firm may pursue differentiation strategy and intellectual capital strategy for isomorphism and demand. Because intellectual capital differentiate firm from rivals. Impact of HRM on demand appears on intellectual capital.

\section{New Paradigm of HRM: Task Performance}

New paradigm of HRM is task performance. Organizations consist of tasks. Tasks are described with job definition. If task performance of employees is higher, organizational performance may increase. SHRM aims to increase organizational performance. Therefore, SHRM is related with task performance of employees. Further, Society for Human Resource Management implements certification programs to increase competence of employees. This certification may be related with task performance. In addition, theoretical knowledge may have an impact on task performance. Tasks may increase organizational performance in firms, and professionals implement tasks in organizations. Therefore, their individual performance in task must become important to HRM department.

Competence of employees increases task performance of employees. For competence, employee (professional) must have theoretical knowledge in his/her business field. For example, HR professionals must have HRM-related theoretical knowledge to effectively implement task in HRM department. On this matter, Society for Human Resource Management carries certification programs and annual conferences for employee competence. Objective of HRM is to have impact on organizational performance (Wright \& McMahan, 1992). Accordingly, theoretical knowledge increases task performance and individual performance of employees. Further, individual performance has an impact on firm performance through department performance.

New paradigm of HRM might be task performance. Because organizations consist of tasks, and professionals implement those tasks in organizations. Therefore, their individual performance at task is important to firm management. 
Tasks may increase organizational performance in firms. And professionals implement tasks in organizations. Therefore, their individual performance in task must become important to HRM department. This study supposes that theoretical knowledge of employees increases task performance of employees.

\section{Case Study: Peter Drucker to Management}

Case study approach would be used in this study. Peter Drucker mentions technology in his book, Frontiers of Management (2015). According to Peter Drucker, professionals or workers must become skilled. It contains both theory and practice. For example, telephone maintenance expert in Bell Atlantic Company must become skilled to achieve customer's satisfaction. Expert must have theoretical knowledge in telephone industry, and must have job experience in telephone maintenance. Similar conditions must exist for firm's professionals. For example, a marketing manager of company possesses theory in marketing and has practical experience in marketing field.

Peter Drucker is management consultant and academic person. He searched for effective management during his career. He presumed that theoretical knowledge may make a manager effective in his/her career.

\section{Impact of HRM on Economy: Talent Management}

First impact of HRM on economy may be seen on talent management, and second may be seen on intellectual capital. Firms create GDP in economy, and managers and departments manage the company. Talent management is to appoint managers to management positions. Further, intellectual capital may generate competitive advantage for firms in isomorphism. For example, rivals may not imitate Steve Jobs, Marc Zuckerberg, Donna Karan, Andre Agassi, and others.

Firms produce national GDP in economy. There are several functions in firm management, and managers operate those functions. They are logistics, supply, stock, finance, accounting, marketing, production, etc. All have managers such as accounting manager, finance manager, marketing manager, etc. Performance of managers is crucial to firm performance. Because performance of managers might become one determinant of firm performance. Therefore, HRM may have an impact on GDP through managers. Because productions and sales of firms affect GDP in economy.

HR is related to performance and talent management. HR aims to increase individual performance, and it aims to have an impact on firm performance through employee performance. Talent management is to appoint talented candidates for management positions. Assuming that talented person (managers) may have an impact on firm performance. Because in their article of 1992, in Journal of Management, Wright and McMahan said that HRM aims to have an impact on firm performance. Furthermore, next phase of capitalism may be human resources. Because human resources are intellectual capital and human capital of company, and human capital may create firm performance for firm. Peter Drucker (2015) symbolized that with knowledge workers.

Talent management may be applied to economy management with figure that: It is described as appointment of executives into management positions. Firms have some business departmants. They are, for example, finance department, logistics department, manufacturing department, marketing, and others. They need managers to effectively manage the department. Because those departments generate organizational performance. It is (talent management) important because performance of managers has an impact on performance of business departments, and all departments' performance comes together, and makes up the firm performance such as market share, sales, profit, and amount of production. Talent management is identified 
with appointing competent managers to management positions in firms.

Scholars argue 4th Industrial Revolution and human resource management relation. Human capital approach may establish relationship between 4th Industrial Revolution and human resource management. Because factory system exists in Industrial Revolution in 1800s. And there are machines and workers in a factory. Therefore, human capital (or machine-worker relationship) may establish relation between HRM and 4th Industrial Revolution. Because there are technologies in factories, and personnel run the technology in firms. Von Mises (2007) discussed idea of Marx as labor value in firms; however, technology-value may affect organizations today.

GDP may be defined with quantity of production, or total of firm's sales. It is expected that managers and professionals increase total sales, profit, and amount and quality of production. Thus, managers may have an impact on national GDP through market sales and production.

\section{HRM and Quantitative}

Venn diagrams may describe inside relations between human resource methods. Venn symbolized sets and subsets of mathematics. And that might figure relationship between HR methodologies.

Major limit of top management in firm management might be "budget limit". Managers are restricted with budget constraints, especially in investment. That might be the case for human resource management. Human resource management in firms may be limited by budget constraints. For example, it is for training. Number of trainees may be determined by budget limit, or compensation or wage is determined by total budget. HR planning, the most prominent HR practice, is limited by personnel budget allocation of firm management. Therefore, mathematic limit may be applied to human resource management. For example, managers' viewpoint against HRM determines strength of HRM in organization. So, managers' point of view of HRM is maybe another limit that restricts human resource application in firms.

Secondly, core application of SHRM in firms might be HR system, and HR system may be established in organizations through set theorem. System theory figures that subsystems establish system in firms. There are some HRM practices that are applied in firms. They are HR planning, staffing, recruitment, compensation, career planning, performance appraisal, training, etc. Those practices may establish subsystem (set) in HR system. And they come together (subsystems), and make up HR system in organization. This is set theorem of mathematic that may be used in human resource management. Because firms may establish HR department in their organizations through set and HR system notion.

To conclude, professional must have theoretical knowledge in his/her career field. Theoretical knowledge may increase task performance of employees and organizational performance, consequently. Because organizations consist of tasks and professionals. Further, according to assumption of this study, managers may have an impact on national GDP through firm performance. Therefore, talent management gains importance for top management in firm. Because firm performance (production, sales) has an impact on GDP in economy.

\section{HR System and Strategic HRM: Described With HPWSs}

HPWSs are a set of HRM practices. MacDuffie (1995) identified HR system as HR bundles. Bundle means interrelated HRM practices. Furthermore, MacDuffie (1995) mentioned Huselid (1993) and Ichinowski (1991)'s studies and found positive relationship between HR system and performance. Simmons (2011), professor of management, identified HPWSs as interconnections between HRM practices. Therefore, fit 
approach is important in HPWS system: fit between HRM practices, and fit between HRM and objectives. For example, connection between pay system and performance appraisal may have an impact on individual performance.

Aim of HPWS is to enhance employee effectiveness. HPWS represents integrative approach between HRM and firms' objectives. Secondly, HPWS is related with performance. Thirdly, fit approach is suitable for HPWS system.

There are internal fit and external fit. Internal fit is related with congruence between HRM practices to which congruence establishes interrelationship among HRM practices. External fit is fit between HRM and organizational objectives.

Wei and Lau (2010) explored mediator between HPWS and firm performance. They find that adaptive capability becomes mediator between HPWS and firm performance. Adaptive capability sets for institutional environment in HPWS.

HPWS is related with human capital. Both HPWS and human capital increase individual performance of employee. Human capital may be defined as schooling and work experience. Therefore, firms apply HPWS system in organization to enhance human capital of employees.

HR system is defined by HR bundles by MacDuffie (1995), which assumes that HR bundle is interrelationship of HRM practices. In HRM, HRM practices are applied through individual. However, for SHRM, HRM practices are applied through interrelationship.

\section{Research Methods}

Huselid and Becker (1997) suggested that HPWS is related with HR system, which comprises of interrelated HRM activities. Case study technic is used in the study. Career management and performance management systems are explored for HR system, and those systems symbolize interrrelationship between HR systems.

Case studies are applied through performance management and career management systems in this study. Firms may implement career management system by applying career mapping, career planning, career advising as bundle.

\section{Case Study I: Career Management System}

Career planning, rotation, career mapping, career plato, and training may establish career management systems in organizations. First of all, firm determines career employees (i.e., star employees). Then, firm develops career planning for star employees. It may use career map methodology for stars to prepare career plans. In career management, employee may join training and education programs for career development. Rotation programs might become another career development activity. Rotation might be described with learning by doing or internship. Firms may pay attention to career plato issue in career planning. That system may establish career management system in firms.

Uysal (2016) suggested "cognitive placement" method in career planning to find star employees, and firm may implement performance management system for star employees. In addition, firm may apply career development program for star employee.

\section{Case Study II: Performance Management System}

Performance evaluation, assessment centers, training, career planning, and compensation policies are 
interrelated HRM practices in performance management. In cognitive placement, there are top group of employees, and there are lowest group employees, to which they have bad performance grade in organizations. Organization may develop performance management policy for bad groups, and for top groups. Organization may prepare career plan for top employees, they may attend training programs, and top employees may obtain performance-based higher compensation. That might be performance management system in organizations.

\section{Conclusions}

Major finding of this study is that firm may apply HR system in its organization through interrelated HRM practices, which is performance management and career management systems in this study. Further, for application of HR system, HR manager of company must have system thinking in management of HR.

Firms may implement HR system in their organizations thorugh application of HR system. Because HR system (HPWS) has an impact on performance than individual HRM practices. Thus, HR manager must have HR bundles perspective for managing human resources.

\section{References}

Barney, J. (1991). Firm resources and sustainable competitive advantage. Journal of Management, 17(1), 99-120.

Brown, E. D. (2006). Implementing a high performance work system. Retrieved from http://www.slideshare.net/helenelena/ implementing-a-high-performance-work-system

Devanna, M. A., Fombrun, C., \& Tichy, N. (1981). Human resources management: A strategic perspective. Organizational Dynamics, 9(3), 51-67.

Drucker, P. (2009). Management. Istanbul: Optimist Publishing.

Drucker, P. (2015). Frontiers of management. Istanbul: Optimist Publishing.

Huselid, M. A., \& Becker, B. E. (1997). The impact of high performance work systems, implementation effectiveness, and alignment with strategy on shareholder wealth. Academy of Management Annual Meetings, USA, January 3th, Human Resource Management Division. Retrieved from http://www.markhuselid.com/pdfs/articles/1997_Shareholder_Wealth.pdf

MacDuffie, J. P. (1995). Human resource bundles and manufacturing performance. Industrial and Labor Relations Review, 48(2), 197-221.

Parsons, C., \& Necochea, R. (2007). High performance work systems in the paper industry. Work Systems. July-August, PaperAge. Retrieved from http://www.paperage.com/issues/july_aug2007/07_2007work_systems.pdf

Simmons, B. L. (2011). High-Performance work systems affect employee attitudes and group performance. Simmons' Blog. Retrieved from http://www.bretlsimmons.com/2011-08/high-performance-work-systems-affect-employee-attitudes-and-grou p-performance/

Uysal, G. (2016). Theory and professionals: Impact of HRM on economy. Journal of Modern Accounting and Auditing, 12(8), 443-446.

Uysal, G. (2017). HRM, organizational psychology and personnel psychology: Linear and simplex analysis of HR. Management Studies, 5(2), 149-152.

Von Mises, L. (2007). Socialism. Ankara, Turkey: Liberte Publishing.

Wei, L., \& Lau, C. (2010). High performance work systems and performance: The role of adaptive capability. Human Relations, 63(10), 1487-1511.

Wright, P. M., \& McMahan, G. C. (1992). Theoretical perspectives for strategic human resource management. Journal of Management, 18(2), 295-320. 